\title{
Doğu Karadeniz Şehirlerinin Marka İletişimi Faaliyetleri Üzerine Bir Araştırma
}

A Research on Brand Communication Activities of Eastern Black Sea Cities

\author{
Erdem TAŞDEMIR*, Emre Ş. ASLAN**, Ali Erkam YARAR*** \\ * Prof. Dr., Trabzon Üniversitesi Illetişim Fakültesi, Fatih Kampüsü, 61335, Söğütlü, Trabzon \\ E- posta: etasdemir29@gmail.com \\ ORCID: 0000-0002-9781-4099 \\ ** Doç. Dr., Trabzon Üniversitesi Illetişim Fakültesi, Fatih Kampüsü, 61335, Söğütlü, Trabzon. \\ E- posta: emresaslan@gmail.com \\ ORCID: 0000-0002-5710-3743 \\ *** (Sorumlu Yazar) Doç. Dr., Necmettin Erbakan Üniversitesi Sosyal ve Beşerî Bilimler Fakültesi, Köyceğiz Yerleşkesi, 42090, Köyceğiz Mah., Demeç Sok., \\ No:39/1, Meram, Konya. \\ E-posta: aeyarar@erbakan.edu.tr \\ ORCID: 0000-0002-0919-314X
}

\section{MAKALE BILGILERI}

Makale ișlem bilgileri:

Gönderilme tarihi: 26 Ocak 2021

Düzeltme: 7 Temmuz 2021

Düzeltme: 10 Eylül 2021

Kabul: 28 Ekim 2021

Anahtar sözcükler: Şehir, Marka şehir, Marka şehir iletişimi.

\section{ARTICLE INFO}

\section{Article history:}

Submitted: 26 January 2021

Resubmitted: 7 July 2021

Resubmitted:10 September 2021

Accepted: 28 October 2021

Key words: City, Brand city, Brand city communication.

\begin{abstract}
ÖZ
Markalaşma için olmazsa olmaz unsurlardan biri de iletișimdir. Markalașma çabası içerisinde yer alan șehirler iletişim faaliyetlerini entegre bir yapı içerisinde yöneterek küresel rekabette avantaj elde etme çabasına girişmektedirler. Bu çerçevede araştırma Doğu Karadeniz Bölgesi'nde yer alan toplam yedi şehir üzerinde gerçekleștirilmiștir. Şehir sakinlerinin kendi șehirlerinin iletișim faaliyetlerine yönelik tutumlarını ölçmeyi amaçlamakta ve bu konuda gerçekleştirilen ilk çalışmalardan biri olarak önem arz etmektedir. Artvin, Bayburt, Giresun, Gümüşhane, Ordu, Rize ve Trabzon şehirlerinde 1221 katılımcıdan toplanan verilerin analiz edildiği bu çalışmaya göre, katılımcılar kendi şehirlerinin iletişim faaliyetlerinin plansız, amaçsız ve koordinasyonsuz olduğunu düşünmektedirler. Ayrıca şehirlerin marka iletişiminde nitelik, performans ve değer faktörlerinin önemli bir rol oynadığı ortaya çıkmıştır.
\end{abstract}

\section{GiRiş}

İletişim faaliyeti toplumsal hayatı üretmenin ve birlikte yaşamanın temel koşuludur (Yaylagül 2010: 12). Marka şehirlerin başarıya ulaşabilmeleri ve sürdürülebilir hale getirebilmeleri, iletişim yönetimi becerisinin performansına bağlıdır. İletişimin niteliği ve hedef kitlede oluşturduğu değer ile ölçülebilen performans, sadece ürünlerinin kalitesine veya dağıtımına bağlı değildir. Ürünlerin benimsenmesi, tüketici beklenti ve ihtiyaçlarının karşılanmasının da ötesinde tüketici ile iletişim kurulması ile gerçekleşmektedir (Karpat Aktuğlu 2018). Destinasyonlar, toplumların kendileri hakkındaki görüşlerini değiştirmek istiyorlarsa, dış dünya ile açık, planlı ve güçlü bir 
iletişim kurmalıdır (Anholt 2011). Marka iletişimi stratejileri şehirlerin, ülkelerin ve bölgelerin iletişim yönlü hedeflerine yol gösterici olarak düşünülebilir.

Doğu Karadeniz şehirlerinin iletişim faaliyetlerine yönelik tutumlar üzerine odaklanan bu araştırma, marka şehir iletişimi stratejilerini keşfetmeyi ve gerçekleşen iletişimin nitelik, performans ve değer boyutları ile ilişkisini ortaya koymayı amaçlamaktadır. Günümüzde marka değerine sahip şehirlere bakıldığında, iletişim faaliyetlerinin başarılı bir şekilde yönetilebildiği anlaşılmaktadır. Son yıllarda yoğun talep patlaması yaşayan Doğu Karadeniz şehirlerinin marka iletişimi süreçlerini yöneten organizasyonlara destek olabilecek araştırma sonuçları, marka şehir alan yazınına da iletişim odaklı katkı sağlayacaktır. Çalışmanın ilk kısmı, marka teorisi bağlamında şehirlerin iletişim faaliyetlerine odaklanmaktadır. Uygulama kısmında ise örneklem çerçevesinde şehir sakinlerinin iletişim faaliyetlerine ilişkin genel tutumları keşfedilmeye çalışılmıştır.

\section{MARKA ŞEHIR ILETiŞiMi}

Bir hikâye anlatan, bir resim çizen ya da bir vaatte bulunan marka (Wilson 2018: 265), tüketicilere ürün kalitesi ve tutarlılığı hakkında fikir verir (Kotler ve Armstrong 2018: 240) ve pazarlama, reklam faaliyetlerinin odak noktasını oluşturur (Aktuğlu 2018: 11). Bu merkeziyetçi yapı, ürünlerin isimler, tasarımlar, dağıtım stratejileri ve reklamlar aracılığıyla tüketicilere farklı biçimlerde sunulmasını sağlamaktadır (Tosun 2018: 625). Ayrıca satıcıya ürünün eşsiz özellikleri konusunda yasal koruma sağlayarak, rakipleri tarafından taklit edilmesini önlemekte ve üreticiye/satıcıya da belirli avantajlar sağlamaktadır (Kotler ve Armstrong 2018: 240). Bu nedenle marka, bir isim ve sembolden daha fazlasidır.

Şehirlerin markalaşma hedefleri ve uygulamalarının en önemli etkileri; yabancı yatırımını artırmak, turizmi teşvik etmek, mirası korumaktır (Kavaratzis, 2004). Şehirlerin bu hedeflerini gerçekleştirebilmeleri markalaşmalarına, markalaşmaları ise iletişim çabalarının başarısına bağlıdır. İletişim bombardımanı altında yaşadığımız bu günlerde (Borça 2007), markaların tüketicilerle iletişim kurabilmesinin yolları artmıştır (Clemmow 2001). Bu durum marka iletişim yönetimini, pazar/tüketici yapıları ile bütünleştirerek tüketiciyle sağlanan etkileşimi derinleştirmeye zorunlu kılar (Uztuğ 2008). Markalar, iletişim faaliyetleri sonucunda, tüketicileri ilettikleri sembolik anlamlarla özdeşleştirmekte ve onların zihninde belirli yönlendirmelerde bulunarak satın alma tercihlerine etkide bulunmaktadırlar (Tosun 2018). Ortaya çıkan yeni gelişmeleri de dikkate alarak hedef kitleleri üzerinde etki yaratabilmek için pek çok platformdan yararlanmakta (Erdil ve Uzun 2009) ve yeni teknolojileri iletişim faaliyetlerinde kullanmaktadırlar. Yaylagül (2010), teknolojinin kendi başına bağımsız bir değişken olarak ele alınamayacağını ifade ederken, teknolojinin ancak zaman ve mekânın örgütlenmesini sağlayan üretim tarzı ile ilişkilendirildiğinde anlam kazanacağını söyleyerek bu görüşü desteklemektedir.

Markalar tüketici ile olan iletişimlerini tutundurma karması öğeleri ile geliştirebilirler. Reklam, marka kimliğinin oluşmasına katkının yanı sıra, markanın sembolik unsurlarını ön plana çıkartan, marka kişiliği oluşturan ve marka kültürüne dair çeşitli nitelikleri tüketiciye aktarabilen bir araçtır (Tosun 2018: 651). Bu aktarımı yaparken, insanların ikna olmalarını, belirli bir düşünceye yönelmelerini, belirtilen konularda dikkatlerini toplamalarını, bilgi almalarını, tutum ve davranış geliştirmelerini hedefler. Halkla ilişkiler, kişisel satış ve satış promosyonu gibi tutundurma karması elemanları, medya ve mecra seçi$\mathrm{mi}$, reklam ve tüm iletişim mesajlarının hazırlanması, tutundurma harcamalarının etkinliğinin ölçülmesi, satış promosyon kampanyalarının belirlenmesi, etkinliğinin ölçülmesi, broşürlerin hazırlanması ve dağıtılması (Koç 2016) gibi iletişim faaliyetleri markaların iletişimini yönlendirebilmektedir. Bu faaliyetlerin içeriği, niteliği, performansı, iletişim kalitesi ve etkileşimi olumlu olduğu müddetçe markalara katkı sağlamaktadır. Stratejik yönetilmeye muhtaç bu süreçte, bugün pek çok kurum ve kuruluş, üretim konusundaki çalışma performansını, pazarlama, iletişim ve satış konusunda gösterememektedir (Bozkurt 
2014). Oysa markalar, tüketicilerin ürün ve ürünün performansı ile ilgili alg1 ve duygularının tümünü temsil ederek, ürün/hizmetin onlar için taşıdığı anlamları kapsar (Kotler ve Armstrong 2018: 251). Sahip oldukları duygular, algılar ve çağrışımlar ile her zaman daha fazlasını ifade ederler. Bireylerin niçin ve nasıl satın aldıklarını ortaya çıkaran temel dürtü ve anlamlar, onların değerleriyle yakından ilgilidir (Koç 2016). Değer, insan eylemlerini seçme, meşrulaştırma ve olayları değerlendirmede bir ölçek olarak görülebilmektedir (Aydın 2011: 93). İnsanlar, kendileri için değerli olan bir şeye sosyal hayatlarında ona yükledikleri anlam kadar yanıt verirler. $\mathrm{Bu}$ anlam inşası, markaların iletişim yönü ile elde etmeye çalıştı̆̆ı amaçların başında gelmektedir.

Şehirlerin Markalaşma Sürecinde Kullanılan İletişim Faaliyetleri

Şehirler, olumlu ya da olumsuz olarak belirli ilişkilerin başladığ 1 yerlerdir (Braun 2008: 94). İnsanlar; yaşadıkları, gezdikleri ve çalıştıkları yerler ile aralarında yakın duygusal bağlar geliştirirler. Bu ilişki ve etkileşim bağları, şehrin genel hedef kitlesi diyebileceğimiz farklı paydaşlarının bir araya gelmesi ile oluşur. Bu yoğunluk, dinamik bir demografik yoğunluktur (Aydın 2011: 244). Bu sebeple şehir denilince, çok sayıda şehirsel ürünü kapsayan bir markadan bahsedilebilir. Ortaya çıkan ilişki, şehirsel ürünlerin kullanılması ile başlayabilir (Braun 2008). Ayrıca insana ait iletişimin en önemli araçsal yapısının dil olduğu unutulmamalıdır. Burada dilden kastedilen sadece sözlü anlatıma dayalı değil, sözlü ve sözsüz tüm ifade biçimlerini içine almaktadır (Aydın 2011: 215). Dolayısıyla, şehirlerin uygulamaya çalıştığı her türlü iletişim faaliyetleri, bu biçimler ile değerlendirilmelidir.

Şehirlerin çok paydaşlı, çok ürünlü ve çok yönlü iletişim pratikleri, şehre yönelik hedeflerin, fikirlerin, iletişimin ve davranışların bir tür uyum içinde olabilmesi için hükümetler, iş dünyası ve sivil toplum arasında sağlam bir iş birliği gereklidir (Anholt 2011). Kâr amacı gütmeyen kurum ve profesyoneller kendilerini hedef kitleye tanitmak için reklamı kullanırken (Kotler ve Armstrong 2018), birçok şehir, içerik yönetim süreçlerini dikkate almadan sayısız basın bültenini servis etmekte, içi boş sloganlar üretmekte ve yayınlamaktadır (İlgüner ve Asplund 2011). Ayrıca şehirler, şehirsel bir iletişim politikası edinerek şehir pazarlama yaklaşımı dahilinde, pazarlama iletişimi pratiklerini izleyebilirler (Braun 2008). Elbette bu pratikler, belli bir sistematik disiplin ve kurumsal bakış açısı ile kontrol edilmeli, davranış bütünlüğü korunmalıdır (Anholt 2011).

Küreselleşmenin ve risklerin artmasıyla stratejik bir işletme aracı olan iletişim (Mattelart 2005: 101), sosyal medyanın ortaya çıkmasıyla daha önemli hale gelmiştir. Sosyal medya, insanların muhatap oldukları şirketler, kurumlar ve ürünler hakkında konuştukları (Safko 2012), deneyimlerini paylaştıkları, riskten kaçınarak bilgi aradıkları (Koç 2016), bu bilgi ve deneyimlerle ürün ya da markalara yönelik tutum geliştirdikleri (Bozkurt 2014), şehirler adına değer taşıyan, şehirsel sunum yaratan, iletişim kuran, değişim ve yeniliğin oluşturulabileceği en önemli platformlardır (Yarar 2017). Öyle ki sosyal medyadaki bilgi alışverişini takip ederek görüş ve deneyimlere ulaşma imkânına kavuşan marka ve kurumlar da kendilerine ait tanımlamaları gözden geçirme fırsatı bulabilmektedirler (Mandelli ve Cantoni 2010).

\section{Araştırma Soruları}

Alanyazın incelendiğinde, şehirlerin sosyal medyayı kullanarak hedef kitle ile etkileşim sağlama, anlık geri bildirimleri alma, karşılıklı görüş alışverişinde bulunma ve şehir ile ilgili görsel ve yazılı öğeleri paylaşma gibi iletişim faaliyetlerini kolayca yerine getirdiği görülmektedir (Zhou ve Wang 2014). Ayrıca stratejik imaj yönetimi yaklaşımı, şehirlerin kendi iletişimlerini sağlamak için bazı seçenekleri getirmiştir (Braun 2008). Buna göre şehirler, markalaşma, iletişim politikası, medya stratejileri, geleneksel şehir tanıtımları, şehir web siteleri, sportif ya da kültürel etkinlikler, şehrin mimarisi, kamu alanları ya da şehirsel tasarımlar, spor kulüpleri, kültürel kurumlar, vatandaşlık katılımları gibi unsurlar ile kendi iletişim faaliyetlerini yönetebilir hale gelmişlerdir. Bu faaliyetler o şehrin değerleri ile şehir sakinleri, turistler, yatırımcılar arasında kurulacak olan bağa dayanmaktadır (Aslan 2018). İletişim 
faaliyetleri ile güçlü bir marka imajı yaratabilmek için tüketicinin zihninde olumlu nitelikler, yararlar ve kişilikler yaratılması gerekmektedir (Kırdar 2003). Başarılı bir şehir yönetimi için ihtiyaç duyulan stratejiler incelediğinde bunlardan birisinin de iletişimin üstünlüğü/niteliği olarak tanımlandığı görülmektedir (İlgüner ve Asplund 2011). Markaya yönelik iletişim çalışmalarının hedefi tüketicide markaya yönelik olumlu bir tutum geliştirmektir (Uztuğ 2003). Sonuç itibariyle iletişim, kaynak ile alıcı arasındaki özgün ilişkiyi değiştirme veya yönetme amacı taşımaktadır (Soydaş 2018). Alanyazın taraması, arzu edilen amaçların gerçekleştirilebilmesi için iletişim faaliyetlerinin belirli bir niteliğe, istenilen sonucu verecek performansa ve değere sahip olması gerektiğini anlatmaktadır. Fakat bu verilere ulaşabilmek için keşfedici bir analiz yapılması gerekmektedir. Bu gerçekler ışığında, şehirlerin marka iletişim faaliyetlerinin incelendiği bu çalışmada, hipotez kurgulamak yerine keşfedici araştırmaya daha uygun olan araştırma soruları üzerinden analizlerin yapılması yerinde olacaktır. Bu çerçevede araştırma soruları aşağıdaki şekilde belirlenmiştir:

- AS1: Doğu Karadeniz şehirlerinin iletişim faaliyetlerine yönelik tutumları etkileyen faktörler nelerdir?

- AS2: Doğu Karadeniz şehir sakinlerine göre şehirlerin marka iletişimi faaliyetleri şehirden şehre farklılaşmakta mıdır?

- AS3: Doğu Karadeniz şehir sakinlerinin, şehirlerinin marka iletişimi faaliyetlerine yönelik tutumu nasildir?

- AS4: Doğu Karadeniz bölgesindeki şehir sakinlerinin, bölge şehirlerinin marka iletişimi faaliyetlerine yönelik tutumları nasıldır?

\section{YÖNTEM}

Bu çalışma, hem şehirlerin iletişim faaliyetlerini ele alması yönüyle hem de o şehirde ikamet eden kişilerin konu ile ilgili tutumlarını ölçmeyi amaçlaması nedeniyle önem arz etmektedir. Son yıllarda özellikle Arapların yoğun ilgi gösterdiği bir bölge haline gelen ve Türk turizm sektöründe adından söz ettirmeye başlayan Doğu Kara- deniz şehirleri (doka.org.tr, 07.02.2021) ${ }^{1}$ üzerine odaklanmaktadır. Doğu Karadeniz Bölgesi'ndeki şehirlere yönelik marka şehir iletişimi üzerine araştırmaların yetersizliği, turizm faaliyetlerinin son yıllarda ivme kazanması ve veri toplama konusundaki kısıtlar nedeniyle araştırma belirli şehirler ile sınırlandırılmıştır. Bu şehirler Doğu Karadeniz Belediyeler Birliği'ne üye olan (www. dkbb.gov.tr 2021)2 "Artvin, Bayburt, Giresun, Gümüşhane, Ordu, Rize ve Trabzon'dan" oluşmaktadır. Toplam yedi şehirde ikamet eden kişiler araştırmanın örneklemini oluşturmaktadır. İç markalaşma yaklaşımı çerçevesinde araştırmacılar tarafından yüz yüze uygulanan araştırma, ilgili şehirlerde ikamet eden 18 yaşından büyük, en az okur yazar, kadın ve erkekler üzerinde Mayıs 2017 ve Temmuz 2019 tarihleri arasinda gerçekleştirilmiştir. Kolayda örnekleme yönteminin kullanıldı $\breve{g}$ bu araştırmada, örneklem büyüklükleri, şehirlerin nüfus oranlarına göre belirlenmiştir. Bölgenin en büyük iki şehri olan Ordu ve Trabzon'da 270, nüfus bakımından ikinci grupta yer alan Giresun ve Rize'de 200, nüfus yoğunluğu diğer şehirlerden az olan Artvin, Bayburt ve Gümüşhane'de ise 125, toplamda 1.315 anket uygulanmıştır. Araştırmanın örneklemi, ana kütlenin 100 milyona kadar olduğu durumlarda $\pm 0,05$ örnekleme hatasıyla 384 olarak hesaplanabileceği gerçeğinden (Yazıcıoğlu ve Erdoğan, 2004: 50) hareketle tüm bölge için 1.315 olarak belirlenmiştir. Araştırma ölçeği, Franzen'in (2020) kitabında yer alan Schlinger'in reklamlara yönelik izleyici tepkisi profili ölçeğinden (1979) ve ilgili alanyazından esinlenilerek oluşturulmuştur. Araştırmacılar tarafından hatalı olduğu yargısına varılanların kapsam dışı tutulmasıyla birlikte 1.221 anket analize tabi tutulmuştur. Bu araştırma çerçevesinde veriler, nicel araştırma yöntemlerinden anket tekniği ile toplanmış ve bir istatistik paket programı aracılığıyla çarpıklık ve basıklık değerlerine ulaşılmış, sıklık, tanımlayıcı istatistik, faktör ve tek yönlü varyans analizi gerçekleştirilmiştir. On dokuz önermenin yer aldığ 1

\footnotetext{
${ }^{1}$ Bkz. https://www.doka.org.tr/dosyalar/editor/files/dogukaradeniz-bolgesinde-arap-turizmi-mevcut-durum-analizi-ve-gelisme-stratejisi

${ }^{2}$ Bkz. http://www.dkbb.gov.tr/?page_id=491
} 
araştırma ölçeğinde, çarpıklık ve basıklık testleri sonucunda üç önermenin parametrik testlerin taşıması gereken kriterleri taşımadığı gözlemlendiğinden kapsam dışı tutulmuş ve 16 önerme faktör analizine tabi tutularak, toplamda üç boyuta ulaşılmıştır.

\section{Ön Test}

Alanında uzman araştırmacıların da görüşleri alınarak gerekli düzeltmelerin yapıldığı ölçek formu ön teste tabi tutulmuştur. Trabzon'da 100 katılımciya uygulanan ve 94 adet anketten elde edilen bulgulara göre ölçeğin Cronbach's Alpha değeri 0,871 olarak bulunmuştur. Bu değerler ölçeğin uygulanması için oldukça güvenilir olduğu şeklinde yorumlanabilir. Örneklem yeterlilik testinin ise (KMO) 0,849 olduğu görülmüştür.

\section{VERILERIN ANALIZI VE BULGULAR}

Araştırmaya katılanların \%36'sının 18-27 yaş aralığında, \%32,6'sının ise $28-37$ yaş aralığında; eğitim durumu açısından \%30,4'ünün lise, $\% 26,2$ 'sinin ön lisans ve $\% 24,1$ 'inin lisans düzeyinde oldukları anlaşılmaktadır. Cinsiyet açısindan katılımciların \%55'inin erkek, \%44,1'inin kadın; medeni durum açısından \%50,5'inin evli, \%48,4'ünün ise bekâr olduğu ortaya çıkmaktadır. Gelir durumları açısından büyük oranda 2.501 TL ile 5.000 TL arasında bir gelire $(\% 37,4)$ sahip olan katılımciların, \%30,4'ü 2.500 TL ve altında gelire sahiptirler. Meslek grupları açısından incelendiğinde katılımcıların \%14,7'sini öğrenciler oluştururken $\% 11,5^{\prime}$ ini memurlar, \%10,1'ini ev hanımları, \%9,5'ini esnaflar, \%7,5'ini işçiler, $\% 5,0^{\prime}$ ini öğretmenler ve geriye kalanlar emekli $(\% 2,8)$, mühendis $(\% 2,4)$, akademisyen $(\% 1,5)$ gibi farklı meslek gruplarından oluştuğu görülmektedir.

\section{Doğu Karadeniz Şehirlerinin İletişim Faaliyetlerine ilişskin Genel Tutumların Keşfedici Faktör Analizi}

Hazırlanan ölçekte 19 madde yer almaktadır. Güvenilirlik katsayısı (Cronbach's Alpha) 0,895 olan bu ölçeğin örneklem yeterlilik testi (KMO) 0,906 'dır. Dolayısıyla iyi derecede güvenilir olan bu ölçekte her bir önerme ile ana kütle arasında anlamlı farklılığın olduğu $(X 2=11970.007, S . D=$ $0,120, p=0,000)$ görülmektedir.

Faktör analizinden önce gerçekleştirilen çarpıklık ve basıklık analizleri sonucuna göre \pm 3 aralığında olmasının uç değerlerin varlığına işaret ettiği iddia eden araştırmalar bulunmaktadır (Karagöz 2016). Bu görüşten hareketle \pm 3 aral1ğında bulunma şartını taşımayan iki önerme ve faktör yığılması içerisinde yer almayan bir önerme, diğer bir ifade ile üç önerme analizden çıarılmıştır (Faktör analizi dışı tutulan maddelerFAD) ${ }^{3}$. Katılımcların, ikamet ettikleri şehirleriyle ilgili bilgilere kolayca ulaşabildiklerini ancak reklam ve tanıtım faaliyetleri gerçekleştirilirken kurumlar arasında vizyon/hedef birlikteliğinin bulunduğu konusunda olumsuz görüş bildirdikleri söylenebilir. Ayrıca olumsuz olarak ifade edilen "bu şehrin dünya çapında marka şehir olabileceğine inanmıyorum" görüşüne olumsuz katılımın olduğu, diğer bir ifade ile şehir sakinlerinin şehirlerinin dünya çapında marka şehir olabileceğine inandıkları söylenebilir.

Üç faktörün elde edildiği ölçeğin faktörleri; nitelik, performans ve değer olarak isimlendirilmiştir. Yedi maddeden oluşan nitelik faktörünü oluşturan önermelerin ortalama değerleri incelendiğinde tamamına olumsuz bir katılım gösterildiği görülmektedir. Bu sonuçlara göre kat1lımcların, web sayfalarının, tanıtım filmlerinin profesyonelce hazırlanmadığı ve yine şehir web sayfalarının ve sosyal medya sayfalarının tanıtıma, tanıtım filmlerinin ise şehre katkı sunacak nitelikte olmadığı yönünde tutum ortaya koydukları görülmektedir. Aynı şekilde katılımcılara göre şehrin reklam ve tanıtım faaliyetleri yeterli düzeyde değildir ve şehrin sosyal medya sayfaları profesyonelce yönetilmemektedir.

Performans faktörünü oluşturan önermelerin ortalamaları incelendiğinde katılımcılar şehirde düzenlenen festivallerin-şenliklerin turist çekme açısından büyük katkı sunduğunu, diğer şehirlerde gerçekleştirilen tanıtım günlerinin, şehrin tanıtımında önemli rol üstlendiği dile getirmişlerdir. Ayrıca reklam ve tanıtım faaliyetleri ger-

\footnotetext{
3 Ölçeğin hazırlanma sürecindeki tüm maddeler istenildiğinde yazarlardan talep edilebilir.
} 
Erdem Taşdemir - Emre Ş. Aslan - Ali Erkam Yarar

Tablo 1. Doğu Karadeniz Şehirlerinin İletişim Faaliyetlerine İlişkin Genel Tutumların Keşfedici Faktör Analizi

\begin{tabular}{|c|c|c|c|c|c|c|c|}
\hline & ORT. & S. S & Çarpık. & Basık... & Faktör1 & Faktör2 & Faktör3 \\
\hline \multicolumn{8}{|l|}{ Faktör 1. Nitelik } \\
\hline $\begin{array}{l}\text { N1-Bu şehrin web sayfaları profesyonelce } \\
\text { hazırlanmıştır. }\end{array}$ & 2,67 & 1,077 & 0,199 & $-0,514$ & 0,852 & & \\
\hline $\begin{array}{l}\text { N2-Bu şehrin tanıtım filmleri profesyonelce } \\
\text { hazırlanmıştır. }\end{array}$ & 2,65 & 1,133 & 0,275 &,- 0624 & 0,841 & & \\
\hline $\begin{array}{l}\text { N3-Bu şehrin web sayfaları tanıtıma katkı } \\
\text { sunacak niteliktedir. }\end{array}$ & 2,78 & 1,091 & 0,078 & $-0,623$ & 0,824 & & \\
\hline $\begin{array}{l}\text { N4-Bu şehrin sosyal medya sayfaları } \\
\text { profesyonelce yönetilmektedir. }\end{array}$ & 2,68 & 1,105 & 0,213 & $-0,554$ & 0,824 & & \\
\hline $\begin{array}{l}\text { N5-Bu şehrin tanıtım filmleri şehre katkı } \\
\text { sunacak niteliktedir. }\end{array}$ & 2,81 & 1,145 & 0,105 & $-0,750$ & 0,815 & & \\
\hline $\begin{array}{l}\text { N6-Bu şehrin reklam ve tanıtım faaliyetleri } \\
\text { yeterli düzeydedir. }\end{array}$ & 2,66 & 1,115 & 0,218 & $-0,700$ & 0,754 & & \\
\hline $\begin{array}{l}\text { N7-Bu şehrin sosyal medya sayfaları tanıtıma } \\
\text { katkı sunacak niteliktedir. }\end{array}$ & 2,88 & 1,115 & $-0,029$ & $-0,668$ & 0,618 & & \\
\hline \multicolumn{8}{|l|}{ Faktör 2. Performans } \\
\hline $\begin{array}{l}\text { P1-Bu şehirde düzenlenen festivaller-şenlikler } \\
\text { turist çekme açııından büyük bir katkı } \\
\text { sunmaktadır. }\end{array}$ & 3,46 & 1,162 & $-0,519$ & $-0,533$ & & 0,761 & \\
\hline $\begin{array}{l}\text { P2-Diğer şehirlerde gerçekleştirilen tanıtım } \\
\text { günleri şehrin tanıtımında önemli rol } \\
\text { üstlenmektedir. }\end{array}$ & 3,39 & 1,060 & $-0,463$ & $-0,325$ & & 0,743 & \\
\hline $\begin{array}{l}\text { P3-Bu şehrin reklam ve tanıtım faaliyetleri } \\
\text { gerçekleştirilirken verilen mesajlar şehrin } \\
\text { gerçek kimliğini yansıtmaktadır. }\end{array}$ & 3,06 & 1,040 & $-0,207$ & $-0,404$ & & 0,681 & \\
\hline $\begin{array}{l}\text { P4-Bu şehrin reklam ve tanıtım faaliyetleri } \\
\text { gerçekleştirilirken verilen mesajlar son derece } \\
\text { özgündür. }\end{array}$ & 3,09 & 1,039 & $-0,198$ & $-0,440$ & & 0,642 & \\
\hline $\begin{array}{l}\text { P5-Bu şehrin reklam ve tanıtım faaliyetlerini } \\
\text { gerçekleştiren kurumlar arasında üst düzeyde } \\
\text { bir iş birliği vardır. }\end{array}$ & 2,79 & 1,026 & $-0,012$ & $-0,411$ & & 0,574 & \\
\hline $\begin{array}{l}\text { P6-Bu şehrin sosyal medya paylaşımlarının } \\
\text { içerikleri oldukça dolu ve zaman zaman kendi } \\
\text { sayfamda paylaşma gereği duyuyorum. }\end{array}$ & 2,90 & 1,134 & 0,013 & $-0,739$ & & 0,524 & \\
\hline \multicolumn{8}{|l|}{ Faktör 3. Değer } \\
\hline $\begin{array}{l}\text { D1-Bu şehir Türkiye'de hak ettiği değeri } \\
\text { görememektedir. }\end{array}$ & 3,63 & 1,186 & $-0,643$ & $-0,454$ & & & 0,929 \\
\hline $\begin{array}{l}\text { D2-Bu şehir bölgede hak ettiği değeri } \\
\text { görememektedir. }\end{array}$ & 3,50 & 1,266 & $-0,505$ & $-0,807$ & & & 0,894 \\
\hline $\begin{array}{l}\text { D3-Bu şehir dünyada hak ettiği değeri } \\
\text { görmemektedir. }\end{array}$ & 3,52 & 1,209 & $-0,508$ & $-0,675$ & & & 0,892 \\
\hline Özdeğer & & & & & 6,999 & 2,615 & 1,268 \\
\hline Açıklanan Varyans & & & & & 43,744 & 16,341 & 7,924 \\
\hline Cronbach's Alpha & & & & & 0,927 & 0,835 & 0,895 \\
\hline KMO Measure of SamplingAdequacy & 0,906 & & & & & & \\
\hline Bartlett's Test of Sphericity & \multicolumn{2}{|c|}{$x^{2}=11970,007$} & \multicolumn{2}{|c|}{ S.D. $=0,120$} & \multicolumn{2}{|l|}{$p=0,000$} & \\
\hline Cronbach's Alpha & 0,895 & & & & & & \\
\hline
\end{tabular}


çekleştirilirken verilen mesajların son derece özgün olduğu, bu mesajların şehrin gerçek kimliğini yansıttığı dile getirilebilir. Fakat şehrin reklam ve tanıtım faaliyetlerini gerçekleştiren kurumlar arasında üst düzey bir iş birliği bulunmadığı ve şehrin sosyal medya paylaşımlarının içerikleri oldukça dolu ve katılımcılar zaman zaman kendi sayfalarında paylaşma gereği duydukları görüşüne katılmadıkları yönünde tutumların ortaya çıktığı anlaşılmaktadır. Üç önermeden oluşan değer faktör incelendiğinde katılımcıların, tüm önermelere olumlu yönde katılım gösterdiği anlaşılmaktadır. Buna göre ikamet edilen şehir bölgede, Türkiye'de ve dünyada hak ettiği değeri görememektedir.

\section{Doğu Karadeniz Şehirlerinin iletişim Faaliyetlerine Yönelik Tutumların Şehirlere Göre Farklılaşma Durumu}

Doğu Karadeniz şehirlerinin iletişim faaliyetlerine yönelik tutumları oluşturan bileşenlerin ikamet edilen şehre göre farklılık gösterip göstermediğini test etmek amaciyla gerçekleştirilen Tek yönlü varyans analizi testi sonuçlarına göre anlamlı farklılık olduğu ortaya çıkmaktadır. Gerçekleştirilen analize göre araştırmaya katılımcıların ikamet ettikleri şehre bağlı olarak iletişimin niteliği $(d f=1180 ; f=11,450 ; p=0,000)$, performansı $(\mathrm{df}=1172 ; \mathrm{f}=11,576 ; \mathrm{p}=0,000)$ ve değeri $(\mathrm{df}=1190 ; \mathrm{f}=2,793 ; \mathrm{p}=0,011)$ bileşenleri açısından anlamlı farklılıklar olduğu ortaya çıkmaktadır. Post hoc testi sonuçlarına göre ise; iletişimin niteliği bileşenin Artvin ile Ordu $(p=0,015)$ arasında; Bayburt ile Giresun ( $p=0,007)$, Gümüşhane $(p=0,036)$, Ordu $(p=0,000)$ ve Trabzon $(p=0,000)$ arasinda, Ordu ile Rize $(\mathrm{p}=0,002)$ arasinda anlamlı farklılık olduğu görülmektedir. Performans bileşenine yönelik tutumlarda ise Artvin ile Bayburt $(p=0,001)$ arasında; Bayburt ile Giresun $(p=$ $0,000)$, Ordu $(p=0,000)$, Rize $(p=0,000)$ ve Trabzon $(p=0,000)$ arasında; Gümüşhane ile Ordu ( $p=$ $0,004)$ ve Trabzon $(p=0,006)$ arasinda anlamlı bir fark bulunmaktadır. Değer bileşeni incelendiğinde ise Giresun ile Trabzon $(p=0,047)$ arasında tutumlar bakımından anlamlı bir farklılık olduğu görülmektedir.

\section{Doğu Karadeniz Şehirlerinin İletişim Faaliyetlerine İlişkin Tutumların Analizi}

Doğu Karadeniz şehirlerinin iletişim faaliyetlerine yönelik tutumlar her şehir özelinde incelenmiştir. Frekans dağılımına göre elde edilen sonuçlar Tablo 2'de yer almaktadır.

\section{Artvin'in Iletişim Faaliyetlerine ilişskin Tutumlar}

Katılımcılar, Artvin'in dünya çapında bir marka şehir olabileceğine inanmaktadırlar. Ancak Artvin'in reklam ve tanitım faaliyetlerinin yeterli düzeyde olmadığını, şehrin tanıtım filmlerinin profesyonel olmadığını, web sayfalarının ve sosyal medya sayfalarının profesyonelce yönetilmediğini düşünmektedirler. Ayrıca şehir tanıtım filmlerinin, web sayfalarının ve sosyal medya hesaplarının tanıtıma katkı sunacak nitelikte olmadığını düşünen katılımcılar, reklam ve tanıtım faaliyetlerini gerçekleştiren kurumlar arasında üst düzeyde bir iş birliğinin bulunmadığını iddia etmektedirler. Reklam ve tanıtım faaliyetlerinde verilen mesajların Artvin' in gerçek kimliğini yansıtmadığını düşünen katılımcılar, şehrin, dünyada Türkiye'de ve bölgede hak ettiği değeri görmediği görüşüne sahiptirler.

\section{Bayburt'un Iletişim Faaliyetlerine Ilişkin Tutumlar}

Katılımciların, Bayburt ile ilgili ifadelere kolayca ulaşabildiklerini ve şehrin dünya çapında marka şehir olabileceğine inandıklarını dile getirdikleri görülmektedir. Bunun dışında, Bayburt'un dünyada, Türkiye'de ve bölgede hak ettiği değeri görmediği görüşüne katılmaktadırlar. Olumsuz tutumlara bakıldığında şehrin reklam ve tanıtımı yeterli düzeyde değildir. Şehrin tanıtım filmlerinin ve web sayfalarının profesyonelce hazırlanmadığını düşünen katılımcılar, sosyal medya sayfalarının profesyonelce yönetilmediğine inanmaktadırlar. Ayrıca, şehrin reklam ve tanıtım faaliyetleri gerçekleştirilirken verilen mesajlar katılımcilara göre özgün değildir ve şehrin gerçek kimliğini de yansıtmamaktadır.

\section{Giresun'un Iletişim Faaliyetlerine iliş̧in Tutumlar}

Şehir ile ilgili bilgilere kolayca ulaşabildiklerini dile getiren katılımcılar, diğer şehirlerde gerçek- 


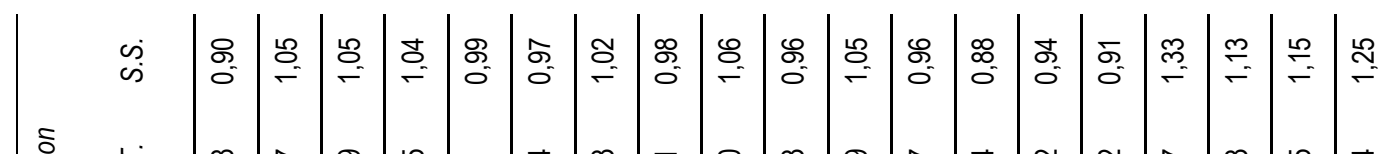

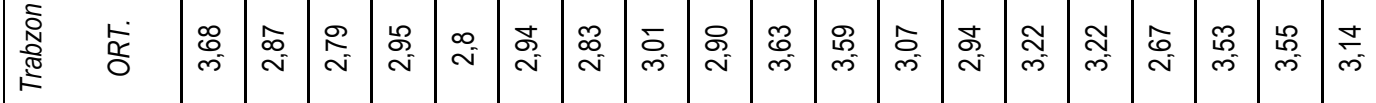
2 \&

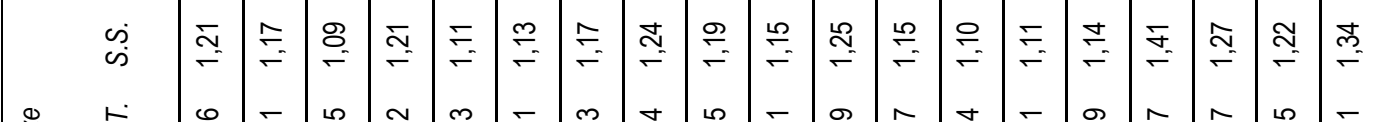

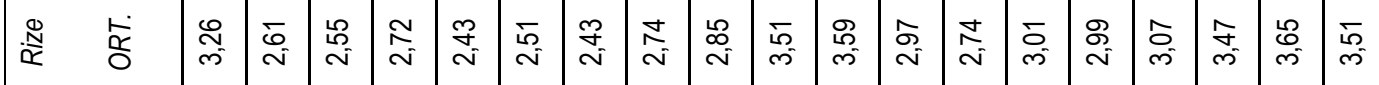

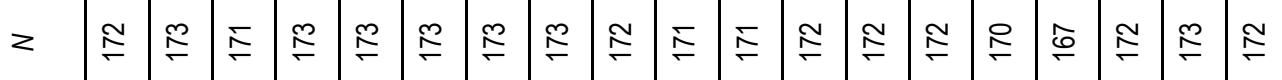
山 żo $z$ i

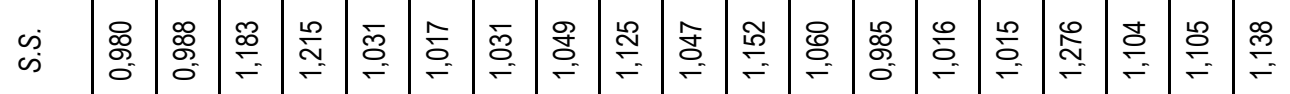

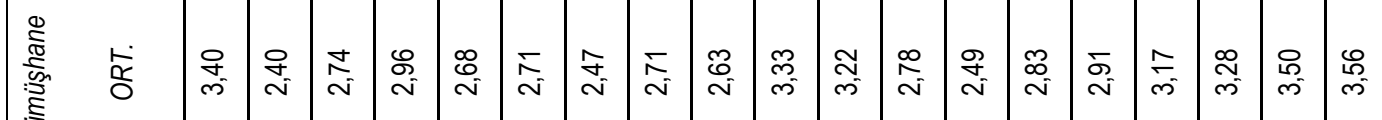

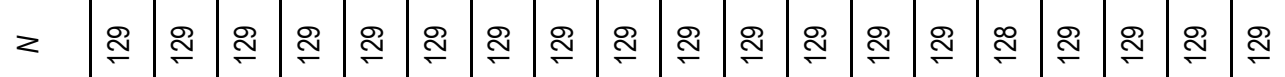
耪

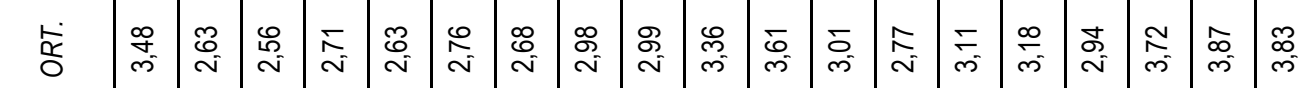
z

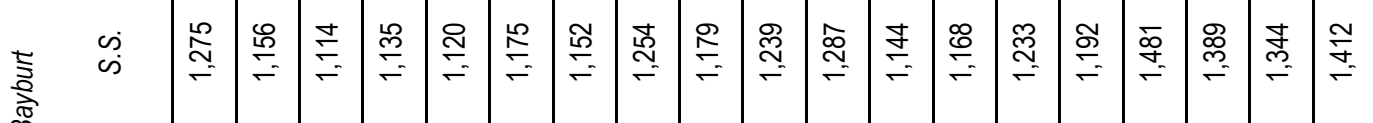

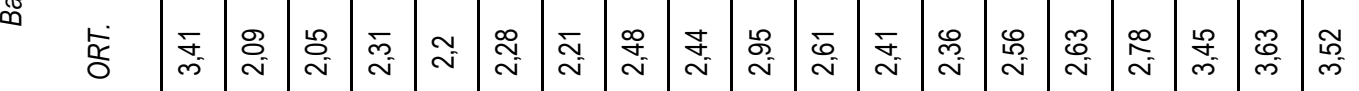

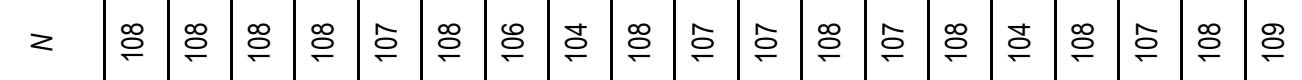
c

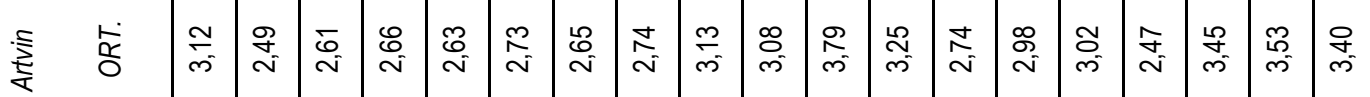

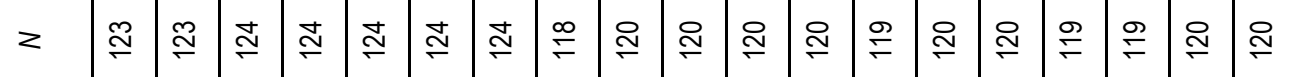
宔 
leştirilen tanıtım günlerinin şehrin tanıtımında önemli rol üstlendiğini ve Giresun'da düzenlenen festivaller-şenliklerin turist çekme açısından büyük katkı sunduğunu düşünmektedirler. Ayrıca katılımcılara göre Giresun, dünya çapında marka şehir olabilecek niteliktedir. Katılımcılar, sosyal medya sayfalarının profesyonelce yönetilmediğini şehrin sosyal medya hesaplarının ve web sayfalarının tanıtıma katkı sunabilecek nitelikte olmadığını dile getirmektedirler. Şehrin sosyal medya sayfalarının içeriklerinin oldukça dolu ve zaman zaman kendi sayfalarında paylaşma gereği duydukları ile ilgili ifadeye düşük katılım gösteren katılımcılar, şehrin reklam ve tanıtım faaliyetleri gerçekleştirilirken kurumlar arasında üst düzeyde bir iş birliğinin bulunduğuna da inanmamaktadırlar. Giresun, dünyada, Türkiye'de ve bölgede hak ettiği değeri görmemektedir.

\section{Gümüşhane'nin Iletişim Faaliyetlerine Ilişsin Tutumlar}

Katılımcıların verdikleri yanıtlara göre, şehir ile ilgili bilgilere kolayca ulaşılabilmektedir. Diğer şehirlerde gerçekleştirilen tanıtım günlerinin şehrin tanitımında önemli rol üstlendiğini, şehirde düzenlenen festivaller ve şenliklerin de turist çekme açısından büyük bir katkı sunduğunu ileri sürmektedirler. Katılımcılara göre şehrin reklam ve tanıtım faaliyetleri gerçekleştirilirken kurumlar arasında vizyon/hedef birlikteliği bulunmamakta, verilen mesajlar şehrin gerçek kimliğini yansitmamakta ve verilen mesajlar özgün bulunmamaktadır. Yine katılımcılara göre Gümüşhane dünya çapında marka bir şehir olamaz (olumsuz ifade) ve bu şehir dünya çapında, Türkiye ölçeğinde ve bölgesinde hak ettiği değeri görmemektedir.

\section{Ordu'nun Iletişim Faaliyetlerine Ilişskin Tutumlar}

Katılımcılar, şehir ile ilgili bilgilere kolayca ulaşabildiklerini, şehrin web sayfalarının tanıtıma katkı sunacak nitelikte olduğunu, şehrin sosyal medya sayfalarının profesyonelce yönetildiğini ve bu sayfaların tanıtıma katkı sunacak nitelikte olduğunu ileri sürmektedirler. Diğer şehirlerde düzenlenen tanıtım günlerinin şehrin tanıtımında önemli rol üstlendiğini ve şehirde düzenlenen festivallerin-şenliklerin turist çekme açısından büyük bir katkı sunduğunu düşünmektedirler. Katılımcılar şehrin reklam ve tanıtım faaliyetleri gerçekleştirilirken verilen mesajların şehrin gerçek kimliğini yansıttığını ve verilen mesajların son derece özgün olduğunu ileri sürmektedirler. Yine katılımcılara göre Ordu dünya çapında marka bir şehir olabilir.

Bu olumlu görüşlerin yanında katılımcılar, bazı olumsuz tutumlara da sahiptir. Katılımcllara göre şehrin reklam ve tanıtım faaliyetleri yeterli düzeyde değildir, tanıtım filmleri ve web sayfaları profesyonelce hazırlanmamıştır. Katılımcılara göre Ordu dünya çapinda, Türkiye'de ve bölgesinde hak ettiği değeri görmemektedir.

\section{Rize'nin Illetişim Faaliyetlerine Iliş̧kin Tutumlar}

Katılımcılara göre, şehir ile ilgili bilgilere kolayca ulaşılabilmektedir. Diğer şehirlerde gerçekleştirilen tanıtım günlerinin şehrin tanıtımında önemli rol oynadığını düşünen katılımcılar, Rize'de düzenlenen festivaller-şenliklerin turist çekme açısından büyük katkı sunduğuna da inanmaktadırlar. Ayrıca katılımcılara göre şehrin reklam ve tanıtım faaliyetleri yeterli düzeyde değildir ve tanitım filmleri, web sayfaları profesyonelce hazırlanmamıştır. Şehrin sosyal medya paylaşımlarının içerikleri de oldukça dolu değil ve zaman zaman kendi sayfalarında paylaşma gereği duyacak nitelikte de değildir. Şehrin reklam ve tanıtım faaliyetleri gerçekleştirilirken kurumlar arasında vizyon/hedef birlikteliğinin olmadığı, kurumlar arasında üst düzeyde bir iş birliğinin bulunmadığ1 ve verilen mesajların da özgün olmadığı görüşünün hakim olduğu katılımcılar, şehrin dünya çapında bir marka şehir olabileceğine de inanmamaktadırlar. Katılımcılar, Rize'nin dünyada, Türkiye'de ve bölgede hak ettiği değeri görmediğini düşünmektedirler.

\section{Trabzon'un Iletişim Faaliyetlerine Iliş̧kin Tutumlar}

Katılımcılar şehir ile ilgili bilgilere kolayca ulaşabilmektedirler. Katılımcılara göre reklam ve tanıtım faaliyetleri gerçekleştirilirken verilen mesajlar, şehrin gerçek kimliğini yansıtmakta ve verilen mesajlar özgündür. Trabzon'un dünya çapında marka bir şehir olabileceğine inanılmak- 
tadır. Bununla birlikte, şehrin web sayfalarının profesyonelce hazırlanmadığını ve sosyal medya sayfalarının profesyonelce yönetilmediğini düşünen katılımcilar, web sayfalarının tanitıma katkı sunacak nitelikte olmadığını ve sosyal medya paylaşımlarının içeriklerinin dolu ve zaman zaman kendi sayfalarında paylaşma gereği duyacak nitelikte olmadığını dile getirmektedirler. Yine katılımcılara göre şehrin reklam ve tanıtım faaliyetlerini gerçekleştiren kurumlar arasında üst düzeyde bir iş birliği yoktur. Katılımcılara göre Trabzon dünyada, Türkiye'de ve bölgesinde hak ettiği değeri görmemektedir.

\section{SONUÇ VE DEĞERLENDIRME}

Markalaşmak isteyen şehirlerin iletişim yönetim biçimlerini inceleyen ve iç hedef kitlenin, diğer bir ifadeyle şehir sakinlerinin, tutumlarını ölçen bu araştırmada, elde edilen veriler incelendiğinde şehirlerin iletişimin faaliyetlerinin nitelik, performans ve değer boyutu açısından farklılık gösterdiği anlaşılmaktadır. Katılımcılar, şehirle ilgili bilgilere kolayca ulaşabildiklerini, reklam ve tanıtım faaliyetleri gerçekleştirilirken şehirlerindeki kurumlar arasında vizyon/hedef birlikteliği bulunduğunu düşündüklerini ifade etmişlerdir. Elde edilen verilerden hareketle, web sayfalar1nin ve tanitım filmlerinin profesyonelce hazırlanmadı ̆̆ 1 , üretilen ürünlerin (web sayfaları, sosyal medya hesapları ve tanıtım filmleri) hem şehrin kendisine hem de tanıtımına katkı sunacak nitelikte olmadığı, reklam ve tanıtım faaliyetlerinin yetersiz olduğu, sosyal medya sayfalarının profesyonelce yönetilmediği, kurumlar arasında üst düzey bir iş birliğinin bulunmadığı, sosyal medya paylaşımlarının içeriklerinin oldukça zayıf olduğu, bu içerikleri katılımcıların kendi sayfalarında paylaşma gereği duymadıkları sonuçlarına ulaşılmıştır. Bu sonuçlardan hareketle, incelenen şehirlerin iletişim faaliyetlerinin plansız, dağınık, koordinasyonsuz ve amaçsız yürütüldügüunü söylemek mümkündür. Halbuki bir iletişim faaliyeti olarak değerlendirilen şehirlerin tanıtım filmleri üzerine gerçekleştirilen bir araştırmada da vurgulandığı gibi oluşturulmak istenen marka şehir imajı belirlenmeli ve bu imaja uygun olarak vaatler, çekimler ve iletişim çabaları gerçek- leştirilmelidir (Aslan, 2018). Hangi amaca hizmet ettiği açıkça belli olmayan bir iletişim faaliyetinin şehirlere ve şehir halkına bir değer katması mümkün değildir. Gerçekleştirilen tüm iletişim faaliyetlerinin belirli bir strateji çerçevesinde ve kurumlar arası eşgüdüm koordinasyonunda ortak bir hedefi başaracak şekilde yürütülmesi gerekmektedir. Bugün sadece Karadeniz Bölgesi değil, Türkiye'de markalaşma amacı güden çoğu şehrin ortak (Şentürk ve Kartal 2020), hedeften uzak, karmaşık ve tutarlılı̆̆ olmayan bir iletişim süreci yönettiği görülmektedir. Elde edilen bu sonuçlar, Avcılar ve Kara'nın (2015) bulguları ile paralellik göstermektedir.

Alanyazın tarandı ğında, İzmir'de şehir markası konusunda çalışmalar yapan iletişim akademisyenleri üzerine gerçekleştirilen bir nitel araştırma sonuçlarına göre seçilen iletişim yöntemleri de şehirlerin markalaşmasında önemli bir unsur olarak karşımıza çıkmaktadır. Bu araştırmaya göre reklamlar, kitlesel ve yapay oldukları için inandırıcılıktan uzak ve olumsuz bir bağlama sahipken, özellikle kişiye özel ve viral olarak verilen mesajlar ve ağızdan ağıza iletişimle desteklenen halkla ilişkiler faaliyetleri daha güçlü bir etkiye sahiptir (Okmeydan, 2018). Dolayısıyla henüz iletişim süreçlerini bile ortak bir stratejiyle, tutarlı ve planlı bir şekilde yönetemeyen şehirlerin hangi iletişim yönteminin daha verimli olacağına karar vermelerini ve kaynaklarını daha verimli kullanmalarını beklemek de mümkün değildir. Bu durum ise şehrin zihinlerde konumlandırma problemlerinin ortaya çıkması, şehir ile ilgili istenilen imajın oluşturulamaması, şehrin marka algısının bozulması, şehir halkının aidiyet hissinin zayıflamasına, markalaşma ve turistik faaliyetlerin şehir halkı tarafından sahiplenmemesi, şehre olan talebin azalmasına dolayısıyla turistik kazanç ve yatırım talebi kaybı gibi sonuçlara yol açabilir (benzer sonuçlar için bkz. Ustakara 2015; Aslan 2018; Yarar 2017).

İletişim tarzları tesadüfen gerçekleşemeyeceği (Wernick 1996) ve kendi başına bırakılacak kadar sıradan bir süreç olmadığ 1 için, şehirlerin iletişim faaliyetlerini özel bir stratejiyle planlamaları gerekmektedir. Ancak Türkiye'nin yönetim sistemi çerçevesinde şehirler incelendiğinde şehri 
oluşturan dinamikler (valilik, belediye, kültür ve turizm müdürlüğü, basın ve halkla ilişkiler birimleri, ticaret odası, sanayi odası gibi kurumlar veya kuruluşlar, milletvekilleri, valiler, belediye başkanları, oda başkanları, STK başkanları gibi kişiler vs.) her ne kadar şehir adına hareket ediyormuş gibi görünseler de tek karar verici merci değillerdir. Her aktör kendi anlayışına, stratejisine ve vizyonuna uygun iletişim çalışmaları yapmaktadır. Bu da ortak bir hedefin gerçekleştirilmesini engellemektedir. Halbuki şehirler iletişim süreçlerini tek bir elden planlayabildiği ve marka ile ilgili inşa edilmek istenen gerçekliği dikkatli bir şekilde yönetebildiği zaman marka olabileceklerdir.

Bazı araştırmacıların veya politikacıların şehirlerini metaforik anlamda bir marka olarak görmeleri ve o şehri bir marka gibi inşa etmeleri sonucunda (Braun, 2008) global anlamda marka olmuş şehirlerin ortaya çıtığ hir adına iletişim faaliyeti gerçekleştiren birçok organizasyonun olduğu Türkiye'de hem geleneksel medya hem de sosyal medya yönetiminin sağlıklı bir şekilde gerçekleştirilebilmesi ve hedef kitlenin görüşleri dikkate alınarak hem kurum hem de birey bazında çerçevesi belirlenmiş bir iletişim süreci ortaya konmasına gerekmektedir. Bu nedenle şehirlerin iletişim faaliyetleri yürütülürken kurumların bir araya gelerek ortak bir vizyonla ve eşgüdümlü bir anlayışla hareket etmeleri, şehri kurumların gücüyle destekleyerek ortak bir değerler sistemi etrafında tek bir vaat çerçevesinde yönetmeleri gerekmektedir. Ashworth ve Page (2011) küresel kent olabilmenin yolunu kamu ve özel sektörün rekabet gücünün arttırılarak, nihayetinde turizm sektörünün başarılı olabilmesine bağlamaktadır. Kozak (2012) ise turizmin başarısı için markayı bir sigorta olarak tanımlamaktadır. Dolayısıyla başarılı bir turizm politikası için şehirlerin yöneticileri ve paydaşları çerçevesinde markalaşma faaliyetleri önemli bir adım olarak görülmelidir. Araştırmanın ortaya çıkardığı bir diğer sonuç, şehir markaları üzerine çalışanların genellikle şehir ile marka ilişkisini kurmakta zorlandıklarıdır. Şehir ile marka ilişkisinin hem yöneticiler hem şehir halkı hem de turistler tarafından kurulabilmesi yine etkili iletişim yönetimiyle mümkündür. Etkili bir ileti- şim yönetimi gerçekleştirmeden şehirlerin markalaşmasından bahsetmek mümkün değildir.

Bu çerçevede marka şehir üzerine araştırma yapanların da çalışmalarında şehirleri üst bir marka olarak ele almaları sağlıklı olacaktır. Ayrıca iç markalaşma sağlanmadan diş markalaşmanın mümkün olmayacağ bu araştırmadan sonra yapılacak araştırmalarda şehirlerin marka iletişimi faaliyetlerinin turistlerin tutumları üzerinden incelenmesinin alana önemli bir katkı sağlayacağı düşünülmektedir.

\section{KAYNAKÇA}

Anholt, S. (2011). Yerlerin Markalaşması: Kimlik, Imaj ve İtibar. İstanbul: İstanbul Ticaret Odas1.

Aslan, E. Ş. (2018). Şehirlerin Markalaşmasında Ortak Aklın Yaratılması: Bir Marka Kent Platformu Oluşturma Arayışı, Çă̆daş Yerel Yönetimler Dergisi, 27 (4): 29-61.

Aslan, E. Ş. (2018). Şehir Tanıtım Filmleri İzleyici Tepkilerinin Marka Kent İmajına Etkisi Üzerine Bir Araştırma, Gümüşhane Üniversitesi İletişim Fakültesi Elektronik Dergisi, 6 (1): 25-50.

Aswort, G. ve Page, S.J. (2011). Urban Tourism Research: Recent Progress and Current Paradoxes, Tourism Management, $32: 1-15$.

Avcılar, M. Y. ve Kara E. (2015). Şehir Markası Kavramı ve Marka Şehir Yaratma Stratejilerine Yönelik Literatür İncelemesi, Sosyal ve Beşeri Bilimler Araştırmaları Dergisi, 16 (34): 76-94

Aydın, M. (2011). Güncel Kültürde Temel Kavramlar. İstanbul: Açılım Kitap.

Borça, G. (2007). Bu topraklardan Dünya Markası Çıkar mı?. Dokuzuncu Basım. İstanbul: MediaCat Kitapları.

Bozkurt, İ. (2014). İletişim Odakl Pazarlama (Tüketiciden Müşteri Yaratmak). İstanbul: MediaCat Kitapları.

Braun, E. (2008). City Marketing: Towards an Integrated Approach. Rotterdam: Erasmus Research Institute of Management (ERIM), ERIM PhD Series in Research and Management.

Clemmow, S. (2001). Reklamda Mükemmele Ulaşmak. İçinde; L. Butterfield (Editör), Strateji Geliştirme (ss. 65-82). (Çev: Muharrem Ayın vd.,). İstanbul: Reklamcılık Vakfi Yayınları.

Doğu Karadeniz Belediyeler Birliği, http://www.dkbb.gov. tr/?page_id=491, Erişim tarihi: 29.01.2021.

Doğu Karadeniz Kalkınma Ajansı, Doğu Karadeniz Bölgesinde Arap Turist, https://www.doka.org.tr/dosyalar/ editor/files/dogu-karadeniz-bolgesinde-arap-turizmi-mevcut-durum-analizi-ve-gelisme-stratejisi.pdf, Erişim tarihi: 07.02.2021.

Erdil, T. S. ve Uzun, Y. (2009). Marka Olmak. İstanbul: Beta Basim.

Franzen, G. (2002). Reklamların Marka Değerine Etkisi. (Çev: Fevzi Yalım). İstanbul: Kapital Medya. 
İlgüner, M. ve Asplund, C. (2011). Marka Şehir. Birinci Basım. İstanbul: Markating Yayınları.

Karagöz, Yalçın (2016). SPSS ve Amos 23 Uygulamalı İstatistiksel Analizler. Ankara: Nobel Akademik Yayıncllık.

Karpat Aktuğlu, I. (2018). Marka Yönetimi: Güçlü ve Başarılı Markalar İçin Temel Illkeler.Yedinci Baskı. İstanbul: İletişim Yayınları.

Kavaratzis, M. (2004). From City Marketing to City Branding: Towards a Theoretical Framework for Developing City Brands, Place Branding, 1(1): 58-73.

Kırdar, Y. (2003). Marka Stratejilerinin Oluşturulması; CocaCola Örneği, Review of Social, Economic\& Business Studies, 3 (4): 233-250.

Koç, E. (2016). Tüketici Davranışı ve Pazarlama Stratejileri: Global ve Yerel Yaklaşım. Yedinci Baskı. Ankara: Seçkin Yayincilik.

Kotler, P. ve Armstrong, G.M. (2018). Pazarlama İlkeleri. İstanbul: Beta Yayınları.

Kozak, N. (2012). Turizm Pazarlamasl. Ankara: Detay Yayınla$\mathrm{r} 1$.

Mandelli A. ve Cantoni L. (2010). Social Media Impact on Corporate Reputation: Proposing A New Methodological Approach, Impacto De Los Medios Sociales En La Reputación Corporativa: Propuesta De UnnuevoAcercamie ntoMetodológico, 27: 61-74.

Mattelart, A. (2005). İletişimin Dünyasallaşması. (Çev: Halime Yücel). İkinci Baskı. İstanbul: İletişim Yayınları.

Okmeydan, S. B. (2018). Marka Kent Olmaya Giden Yol: İzmir'de Kent Markası Çalışan İletişim Akademisyenlerine Yönelik Bir Araştırma, The Journal of International Scientific Researches, 3 (4): 111-134.
Safko, L. (2012). The Social Media Bible- Tactics, Tools EStrategies For Business Success. New Jersey: John Wiley.

Soydaş, N. (2018). İletişim Bence: Dumandan Hashtag'e İletişim. İstanbul: İnkılap Kitabevi.

Şentürk, E. E. ve Kartal, C. (2020). Türkiye'de Kent Markalaması Alanında Yapılan Akademik Çalışmalar Üzerinde Bir İnceleme, Uluslararası İşletme, Ekonomi ve Yönetim Perspektifleri Dergisi, 4 (1): 26-41.

Tosun, N. B. (2018). Marka Yönetimi. İstanbul: Beta Yayınları.

Ustakara, F. (2015). Kent Markalama: Stratejik İletişim Bağlamında Marka Şehir Projesi. Konya: Literatürk Yayınları.

Uztuğ, F. (2003). Markan Kadar Konuș! Marka İletişimi Stratejileri. İkinci Bask1. İstanbul: Mediacat Yayınları.

Uztuğ, F. (2008). Reklamcilıkta Anna Karenina İlkesi: Kesmece Reklam Mümkün Müdür. İstanbul: Beta Yayıncıllk.

Wernick, A. (1996). Promosyon Kültürü: Reklam, İdeoloji ve Sembolik Anlatım. (Çev: Osman Akınhay). Ankara: Bilim ve Sanat Yayınları.

Wilson, A.J. J. (2018). Halal Branding. United Kingdom: Claritas Books.

Yarar, A. E. (2017). Sosyal Medya İletişimi. İçinde Taşdemir E. ve Aslan E.Ş (Editörler), Sosyal Medya ve Şehirlerin Sosyal Medya Kullanımı. ss. 55-75. Ankara: Gece Kitaplığı.

Yaylagül, L. (2010). Kitle İletişim Kuramları: Egemen ve Eleştirel Yaklaşımlar. Ankara: Dipnot Yayınları.

Yazıcıoğlu, Y. ve Erdoğan, S. (2004). SPSS Uygulamalı Bilimsel Araştırma Yöntemleri. Ankara: Detay Yayıncılık.

Zhou, L. ve Wang, T. (2014). Social Media: A New Vehicle for City Marketing in China, Cities, 37: 27-32. 

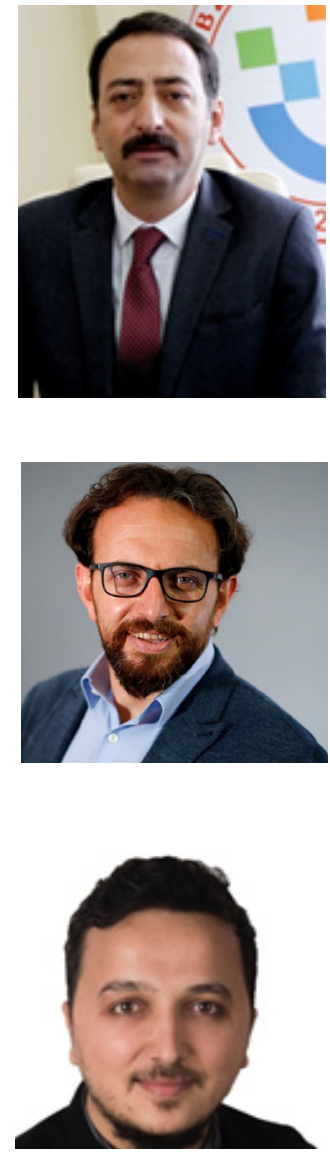

\section{Erdem TAŞDEMIR}

Selçuk Üniversitesi Illetişim Fakültesi Halkla Ilişkiler ve Tanııım Bölümü’nden mezun oldu (1997). Yüksek lisans derecesini Selçuk Üniversitesi'nden Gazetecilik Anabilim Dalı'ndan (2000), doktora derecesini de Halkla iliş̧kiler ve Tanıtım Anabilim Dalı'ndan aldı (2005). Selçuk Üniversitesi'nde çalışmaya başladı (1998). Karadeniz Teknik Üniversitesi'nde çalışmaya başladı (2006). Doçentlik unvanını Halkla İlişkiler alanında aldı (2012). Profesörlüğe Karadeniz Teknik Üniversitesi'nde yükseltildi (2018). Halen Trabzon Üniversitesi iletişim Fakültesi'nde görev yapmaktadır. Temel çalışma alanları; halkla ilişkiler, kişilerarası iletişim, kurumsal iletişim ve sosyal medyadır.

\section{Emre Ş. ASLAN}

Selçuk Üniversitesi İletişim Fakültesi Halkla İlişkiler ve Tanıtım Bölümü’nden mezun oldu (2005). Yüksek lisans derecesini Selçuk Üniversitesi Araştırma Yöntemleri Anabilim Dalı'ndan (2008), doktora derecesini ise Gazi Üniversitesi Halkla Iliş̧kiler ve Tanıtım Anabilim Dalı'ndan aldı (2014). Gümüşhane Üniversitesi'nde çalışmaya başladı (2010) Doçentlik unvanını İletişim Çalışmaları alanında aldı (2019). Halen Trabzon Üniversitesi Illetişim Fakültesi'nde görev yapmaktadır. Temel çalışma alanı/ları; mesaj, mesajın inşası, marka, reklam, reklam stratejileri, sosyal medyadır.

\section{Ali Erkam YARAR}

Selçuk Üniversitesi İktisadi ve İdari Bilimler Fakültesi İ̧̧letme Bölümü'nden mezun oldu (2007). Yüksek lisans derecesini Selçuk Üniversitesi'nden Reklamcılık ve Tanıtım Dalı'ndan (2010), doktora derecesini de Selçuk Üniversitesi'nden Halkla ïlişkiler ve Reklamclık Anabilim Dalı'ndan aldı (2016). Necmettin Erbakan Üniversitesi'nde çalışmaya başladı (2014). Doçentlik unvanını Reklamcılık alanında aldı (2021). Halen Necmettin Erbakan Üniversitesi Sosyal ve Beşeri Bilimler Fakültesi'nde görev yapmak- 